\title{
THE METABOLISM OF CHYLOMICRON CHOLESTEROL ESTER IN THE RAT
}

\author{
By DeWITT S. GOODMAN \\ (From the Laboratory of Cellular Physiology and Metabolism, National Heart Institute, \\ Bethesda, Md.)
}

(Submitted for publication March 15, 1962; accepted June 21, 1962)

The lymphatic transport of cholesterol is of great quantitative importance in the over-all metabolism of cholesterol. It is now well established that exogenous cholesterol is absorbed almost exclusively by way of the intestinal lymph $(1,2)$, where most of the newly absorbed cholesterol is found esterified, in the chylomicron fraction (3, 4). Estimates of the extent of esterification have varied from 90 per cent at the peak of cholesterol absorption (3) to an average of $72 \pm 6$ per cent over a wide range of absorption (4). In addition, a considerable amount of endogenous cholesterol from the bile and the intestinal mucosa is absorbed and transported in an identical fashion.

Surprisingly little detailed information exists, however, on the metabolic history of newly absorbed cholesterol after the cyhlomicra have entered the vascular compartment. Most of this cholesterol is first taken up by the liver $(5,6)$, where there is a delay of several hours before subsequent mixing with the cholesterol of blood and other tissues (5). During the first 1 to 2 hours after the intravenous injection into rats of chyle containing absorbed $\mathrm{H}^{3}$-cholesterol, the specific radioactivity of the esterified cholesterol in liver was several times higher than that of the free cholesterol (6). In contrast, a number of studies have revealed much of the details of the metabolism after absorption of the major component of chyle, the triglyceride fatty acids $(7-11)$.

One of the reasons for the relative lack of information about the metabolism of chylomicron. cholesterol is the uncertainty arising from the exchangeability of the free cholesterol in chyle and in blood. Both in vivo (12) and in vitro (13) studies have shown that free cholesterol in chylomicra, plasma, and red blood cells is readily exchangeable, so that labeled cholesterol in one of these locations can partially equilibrate with the others in only a few minutes. This property tends to reduce the validity of metabolic interpretations based on the distribution of labeled cholesterol.

In the present study, an attempt was made to remove most of the readily exchangeable free $\mathrm{C}^{14}$ cholesterol in chylomicra by preliminary in vitro equilibrations with blood. The resulting chylomicra, containing almost 90 per cent of the label as esterified cholesterol, were then injected into intact rats, and the tissue distribution and free: ester ratio of $\mathrm{C}^{14}$-cholesterol observed for 24 hours.

\section{METHODS}

One hundred microcuries of $4-\mathrm{C}^{14}$-cholesterol $(17 \mathrm{mg}$ per mc, Nuclear-Chicago) dissolved in $0.6 \mathrm{ml}$ olive oil were given by gastric intubation to a rat whose cysterna chyli had been cannulated the previous day. During the subsequent 24 hours, $60 \mathrm{ml}$ of milky chyle containing a total of $54 \mu \mathrm{c}$ of $\mathrm{C}^{14}$ was collected. This chyle was used in all experiments herein reported.

Equilibrations in vitro were performed in Erlenmeyer flasks, with gentle shaking in a metabolic incubator at $37^{\circ} \mathrm{C}$. Chylomicra were separated from other components and simultaneously washed by being placed under isotonic saline in a plastic centrifuge tube and centrifuged at $25,000 \mathrm{rpm}$ for 25 minutes in the $\mathbf{4 0}$ roter of a Spinco model $\mathrm{L}$ ultracentrifuge. The tubes were sliced just below the concentrated chylomicron layer and the chylomicra resuspended in saline solution by repeated injection through a 5-inch no. 19 hypodermic needle. Samples of the resuspended chylomicra and of the redispersed solution and sediment from the bottom part of the sliced centrifuge tubes were added to 5 to 10 volumes of isopropanol: hexane: $1 \mathrm{~N} \mathrm{H}_{2} \mathrm{SO}_{4} 40: 10: 1$ parts by volume (14); enough water and light petroleum ether, with bp 36 to $54^{\circ} \mathrm{C}$ was added to split the mixture into two phases of approximately equal volume. The upper phase was removed and the lower phase extracted twice more with equal volumes of light petroleum ether. The combined hexane-petroleum ether extracts were evaporated, and the residue was chromatographed, or assayed for radioactivity, or both. This procedure quantitatively extracts all the neutral lipids, including free and esterified cholesterol, from a solution.

The experimental animals were 10 male SpragueDawley rats weighing 190 to $215 \mathrm{~g}$ and fasted for 16 to 
18 hours before the time of injection. The rats were kept fasting throughout the experiment. Each rat received $2 \mathrm{ml}$ of labeled chylomicra by injection into a tail vein. At specified time intervals, the animals were anesthetized with ether, and as much blood as possible, from 5 to $7 \mathrm{ml}$, was withdrawn from the abdominal aorta into a syringe moistened with a heparin solution. Organs and tissues were removed as rapidly as possible in the following order: piece of liver, epididymal fat bodies, adrenals, kidneys, spleen, right adductor muscle, heart ventricles, and lungs. The tissues were rinsed, blotted dry, weighed, and extracted in ethanol-acetone $1: 1$ by volume as described by Bragdon and Gordon (9). The rest of the liver was weighed and discarded. The carcass and remaining viscera were ground and extracted (9). Excreta were not collected. Portions of whole blood were extracted directly in isopropanol-hexane as described above. The blood was then centrifuged in small graduated tubes, and the red cell and plasma volumes recorded. The plasma was removed, the red cells were washed twice with isotonic saline, and then samples of plasma and washed red cells were also extracted in isopropanol-hexane. These extraction solutions were left for several hours, with occasional mixing, before being split into two phases with water and petroleum ether. All the radioactivity in the various blood fractions was found to be completely extracted by this procedure.

Portions of the various tissue and carcass extracts were chromatographed on aluminum oxide to separate free and esterified cholesterol. Samples were applied in petroleum ether solution to small columns containing $2 \mathrm{~g}$ alumina (Woelm, neutral, grade II). The esterified cholesterol was eluted with $12 \mathrm{ml}$ benzene: petroleum ether $1: 1$ by volume, and the free cholesterol was then eluted with $12 \mathrm{ml}$ acetone: ethyl ether $1: 1$ by volume. Appropriate tests have indicated that this simple procedure quantitatively separates the free and esterified cholesterol in a mixture (15). The eluates were evaporated dry, dissolved in $15 \mathrm{ml} 0.5$ per cent diphenyloxazole in toluene, and assayed for $\mathrm{C}^{14}$ in a Packard liquid scintillation spectrometer, with an efficiency of about 55 per cent. Correction was made for quenching, when indicated, by use of an internal standard.

The distribution in organ and tissue of $\mathrm{C}^{14}$-cholesterol in each animal was calculated from the observed $\mathrm{C}^{14}$ in the weighed and measured samples used for analysis. From the data of Castor, Poncelet, Simon, and Armstrong (16), depot fat was taken as 7.08 per cent and skeletal muscle as 45.5 per cent of the body weight of each rat. The plasma volume was taken as 3.5 per cent of the body weight and the red cell volume determined from the measured hematocrit. An internal check on the values for blood, plasma, and red cells was provided by the separate analyses performed on whole blood, plasma, and washed red cells. In each case, the sum of the values for plasma and red cells closely approximated the measured values for whole blood, both for total recovery and for percentage of free $\mathrm{C}^{14}$-cholesterol. Average values for total recoveries in blood were used in the final tabulation. In all cases, tissue recoveries were corrected for the amount of blood expected to be present, as estimated from other studies in this laboratory, in which $\mathrm{I}^{131}$ serum albumin was injected into rats of similar size and the amount of $\mathrm{I}^{131}$ in each tissue measured. This correction was determined as described by Bragdon and Gordon (9), and was of moderate quantitative significance in only a few of the tissues of the pair of rats studied after 5 minutes.

The fatty acid compositions of the cholesterol ester fractions from rat liver, serum, and adrenal glands were compared directly. Pooled livers, adrenal glands, and sera were obtained from 5 fed male rats weighing about $175 \mathrm{~g}$ each. The livers and adrenal glands were weighed and homogenized with measured volumes of $0.1 \mathrm{M}$ phosphate buffer at $\mathrm{pH} 7.4$ and $0.15 \mathrm{M} \mathrm{NaCl}$, respectively. Portions of these homogenates and of sera were analyzed for their content of free and esterified cholesterol. Other portions were extracted with $\mathrm{CHCl}_{3}: \mathrm{MeOH} 2: 1$ by volume and then chromatographed to isolate the cholesterol ester fraction from each total lipid extract. Fivegram columns of silicic acid (Unisil, 100-200 mesh, Clarkson Chemical Co., Inc.) were employed and the sterol ester fractions eluted with 16 per cent benzene in hexane as described by Horning, Williams, and Horning (17). The recovery of cholesterol ester was rigorously checked by the prior addition to each sample of a tracer amount of $\mathrm{H}^{3}$-cholesteryl linoleate, synthesized as described elsewhere (15). More than 97 per cent of the $\mathrm{H}^{3}$ was recovered in each sterol ester elution. A measured amount of $n$-heptadecanoic acid was then added to each cholesterol ester fraction to provide an internal check against contamination of this fraction with other lipids, e.g., triglycerides. Comparison of the mass of this fatty acid with the mass of all other fatty acids, as determined by gas-liquid chromatography, and with the fatty acid mass expected from the cholesterol analyses demonstrated that such contamination did not occur in any of the samples.

The cholesterol ester fatty acids were analyzed by gasliquid chromatography after formation of the fatty acid methyl esters by transmethylation (18). The analytic column contained 10 per cent ethylene glycol-adipate polyester on Celite, and was operated at $198^{\circ} \mathrm{C}$. The detector was an ionization chamber modified and kindly made available by Dr. Arthur Karmen, and was shown to respond linearly to mass in the range employed. The relative mass of each fatty acid in each analysis was determined by triangulation. The different fatty acids were identified by comparison of their retention time with those of standard fatty acid methyl esters.

Analyses of free and ester cholesterol were performed as described by Sperry and Webb (19), and analyses of total lipid by the method of Bragdon (20).

\section{RESULTS}

The first objective of this investigation was to remove most of the readily exchangeable free $\mathrm{C}^{14}$ - 
cholesterol from the labeled chylomicra. It was hoped that this would provide chylomicra labeled almost exclusively with esterified cholesterol, the subsequent metabolic history of which could then be studied more clearly in the absence of labeled -and exchangeable-free cholesterol. To achieve this aim, chylomicra were equilibrated in vitro with blood and then reisolated by centrifugation. The experiment summarized in Table I demonstrated the partially selective removal of labeled free cholesterol from chylomicra during such an equilibration. In this experiment, whole chyle was first centrifuged to obtain the washed chylomicra, sample b1 of Table I. More than 99 per cent of the radioactivity in the whole chyle was recovered in the sum of the chylomicron plus the bottom fractions, with 70 per cent of the radioactivity present in the chylomicra. The percentage of the $\mathrm{C}^{14}$ present as free cholesterol was virtually the same in the two centrifugal fractions, 30 to 31 per cent. The washed chylomicra were then equilibrated with an equal volume of rat whole blood for 1.5 hours at $37^{\circ} \mathrm{C}$ and again isolated by centrifugation, as sample $\mathrm{c} 1$ of Table I. Only 19.7 per cent of the $\mathrm{C}^{14}$-cholesterol in the chylomicra was now free. In contrast, 65.4 per cent of the radioactivity recovered in the bottom zone of the centrifuge tube, i.e., in the whole blood after removal of the chylomicra, was present as free cholesterol. In the two centrifugal fractions, a total of 97 per cent of the esterified and 93 per cent of the free $\mathrm{C}^{14}$-cholesterol was recovered. This showed that the reduction in the percentage of $\mathrm{C}^{14}$ present in the chylomicra as free cholesterol was due to a much greater exchange of labeled free cholesterol with the components of blood rather than to some other process, such as a change in the over-all free : ester ratio of the labeled cholesterol. In addition, the relative contribution of the plasma and red cells to the exchange process was examined by analyzing a duplicate equilibration of chylomicra with whole blood. In removing the bottom fraction of this duplicate sample after centrifugation, the packed red cell pellet was not resuspended, so that only the plasma was removed and analyzed. The data for section $d$ of Table I show that this plasma contained most of the $\mathrm{C}^{14}$-cholesterol ester, but only about one-third of the free $\mathrm{C}^{14}$-cholesterol, present in the bottom fraction of section $\mathrm{c}$ of Table $\mathrm{I}$, including the red cells. This indicated that red cells were relatively more important than plasma in effecting the selective transfer of labeled free cholesterol from the chylomicra. A similar conclusion was also reached in another experiment directly comparing the effectiveness of whole blood and plasma.

After these preliminary experiments, the entire remaining volume of labeled chyle was equili-

TABLE I

A nalyses of whole chyle and of washed chylomicra before and after equilibration with whole blood *

\begin{tabular}{|c|c|c|c|c|c|c|}
\hline \multirow[b]{2}{*}{ Fraction analyzed } & \multicolumn{3}{|c|}{$\mathrm{C}^{14}$-cholesterol } & \multirow{2}{*}{$\begin{array}{c}\% \\
\text { Ci4 } \\
\text { Free }\end{array}$} & \multicolumn{2}{|c|}{ Recovery of $\mathrm{C}^{14}$} \\
\hline & Total & Ester & Free & & $\overline{\text { Ester }}$ & Free \\
\hline & \multicolumn{3}{|c|}{$c p m \times 10^{-4}$} & & \multicolumn{2}{|c|}{$\%$} \\
\hline a Whole chyle & 89.25 & 61.61 & 27.64 & 31.0 & $(100)$ & $(100)$ \\
\hline \multicolumn{7}{|l|}{ b Washed chylos } \\
\hline $\begin{array}{l}1 \text { Top: chylos } \\
2 \text { Bottom } \\
\text { Sum of } 1+2\end{array}$ & $\begin{array}{l}62.50 \\
26.44 \\
88.94\end{array}$ & $\begin{array}{l}42.88 \\
18.54 \\
61.42\end{array}$ & $\begin{array}{r}19.62 \\
7.91 \\
27.52\end{array}$ & $\begin{array}{l}31.4 \\
29.9 \\
30.9\end{array}$ & $\begin{array}{l}69.6 \\
30.1 \\
99.7\end{array}$ & $\begin{array}{l}71.0 \\
28.6 \\
99.6\end{array}$ \\
\hline \multicolumn{7}{|l|}{ c Equil. with blood } \\
\hline $\begin{array}{l}1 \text { Top: chylos } \\
2 \text { Bottom-whole blood } \\
\text { Sum of } 1+2\end{array}$ & $\begin{array}{l}46.01 \\
14.01 \\
60.02\end{array}$ & $\begin{array}{r}36.94 \\
4.84 \\
41.79\end{array}$ & $\begin{array}{r}9.07 \\
9.17 \\
18.24\end{array}$ & $\begin{array}{l}19.7 \\
65.4 \\
30.4\end{array}$ & $\begin{array}{l}86.1 \\
11.3 \\
97.4\end{array}$ & $\begin{array}{l}46.2 \\
46.7 \\
93.0\end{array}$ \\
\hline \multicolumn{7}{|l|}{$\mathrm{d}$ Duplicate of $\mathrm{c}$} \\
\hline $\begin{array}{l}1 \text { Top: chylos } \\
2 \text { Bottom, less RBC } \\
\text { Sum of } 1+2\end{array}$ & $\begin{array}{r}48.80 \\
7.05 \\
55.85\end{array}$ & 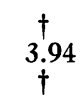 & ${ }_{i}^{\dagger}+11$ & $\underset{t}{+}$ & $\begin{array}{c}\dagger \\
9.2 \\
\dagger\end{array}$ & $\begin{array}{c}t \\
15.9 \\
\dagger\end{array}$ \\
\hline
\end{tabular}

* All values have been adjusted to the equivalent of $1 \mathrm{ml}$ whole chyle.

$\uparrow$ Analysis not done, or calculation not applicable.

$\ddagger \mathrm{RBC}=$ red blood cells. 
TABLE II

Analyses of chylomicra during a series of 4 equilibrations with blood *

\begin{tabular}{|c|c|c|c|c|c|c|c|c|}
\hline \multirow{2}{*}{$\begin{array}{l}\text { Chylos } \\
\text { after } \\
\text { equil. no. }\end{array}$} & \multicolumn{3}{|c|}{ Cholesterol } & \multirow{2}{*}{$\begin{array}{l}\mathrm{Cl}^{14} \\
\text { Free }\end{array}$} & \multicolumn{2}{|c|}{$\begin{array}{l}\text { Net recovery } \\
\text { of } \mathrm{C}^{14 \dagger}\end{array}$} & \multicolumn{2}{|c|}{$\begin{array}{l}\text { Recovery of } C^{14} \\
\text { per equil. } \neq\end{array}$} \\
\hline & Total & Ester & Free & & Ester & Free & Ester & Free \\
\hline & \multicolumn{3}{|c|}{$c p m \times 10^{-6}$} & $\%$ & \multicolumn{2}{|c|}{$\%$} & \multicolumn{2}{|c|}{$\%$} \\
\hline $\begin{array}{c}0, \text { start } \\
1 \\
2 \\
3 \\
4\end{array}$ & $\begin{array}{l}34.70 \\
25.68 \\
19.81 \\
17.80 \\
14.94\end{array}$ & $\begin{array}{l}24.33 \\
20.19 \\
16.61 \\
15.28 \\
12.98\end{array}$ & $\begin{array}{r}10.37 \\
5.49 \\
3.20 \\
2.52 \\
1.96\end{array}$ & $\begin{array}{l}29.9 \\
21.4 \\
16.2 \\
14.2 \\
13.1\end{array}$ & $\begin{array}{l}(100) \\
83.1 \\
68.4 \\
63.1 \\
53.4\end{array}$ & $\begin{array}{l}(100) \\
53.1 \\
30.9 \\
24.3 \\
18.9\end{array}$ & $\begin{array}{l}83.1 \\
82.4 \\
92.1 \\
85.0\end{array}$ & $\begin{array}{l}53.1 \\
58.2 \\
78.8 \\
77.7\end{array}$ \\
\hline
\end{tabular}

* All values have been adjusted for samples removed, and are directly comparable.

+ Recovery of $\mathrm{C}^{14}$ compared with the original chylomicra, taken as 100 per cent.

$\ddagger$ Recovery of $\mathrm{C}^{14}$ compared with the preceding chylomicron sample, which was used for equilibration.

brated with blood in order to remove free $\mathrm{C}^{\mathbf{1 4}}$ cholesterol selectively by exchange. Four equilibrations were carried out sequentially on the seventh day after the original collection of the chyle. In each equilibration, the chylomicra were incubated for 1 hour at $37^{\circ} \mathrm{C}$ with an equal volume of an artificial blood consisting of packed human red cells, rat plasma, and isotonic saline solution, in proportions of $7: 3: 2$. The chylomicra were then reisolated by centrifugation and re-equilibrated. After the fourth equilibration, the chylomicron suspension was stored overnight at $4^{\circ} \mathrm{C}$ for injection into rats the next morning.

The results of this entire treatment of the labeled chyle are shown in Table II. The percentage of $\mathrm{C}^{14}$-cholesterol present as free cholesterol was substantially reduced during the first two equilibration periods, from 29.9 to 16.2 per cent. Two more equilibrations resulted in only a small further decrease in this value, to 13.1 per cent. These data suggest that part of the free cholesterol in chylomicra was less readily exchangeable than the rest, and imply the existence of some inhomogeneity in the physical state of this cholesterol. The final recovery of esterified cholesterol- $\mathrm{C}^{14}$ in chylomicra was 53.4 per cent and of free cholesterol- $\mathrm{C}^{14} 18.9$ per cent. The chylomicra obtained at the end of the series of equilibrations contained 74 per cent of the total lipid present before equilibration; most of the remainder probably represents unavoidable losses encountered during manipulations. The treated chylomicron suspension appeared the same the following morning as an untreated control chylomicron suspension both by gross and by microscopic inspection. Two $\mathrm{ml}$ of this suspension

TABLE III

Total recoveries of $C^{14}$-cholesterol after intravenous injections of 959,060 $\mathrm{cpm}$

\begin{tabular}{|c|c|c|c|c|}
\hline \multirow[b]{2}{*}{ Rat no. } & \multirow[b]{2}{*}{ Time* } & \multicolumn{2}{|c|}{ Total recovery of $\mathrm{C}^{14}$} & \multirow{2}{*}{$\begin{array}{l}\text { Recovered } \mathrm{C}^{14} \\
\% \text { free }\end{array}$} \\
\hline & & $\mathrm{cpm}$ & $\%$ of dose & \\
\hline $\begin{array}{l}4 \\
5\end{array}$ & $\begin{array}{l}5 \mathrm{~min} 3 \mathrm{sec} \\
5 \mathrm{~min} 15 \mathrm{sec}\end{array}$ & $\begin{array}{l}894,502 \\
835,356\end{array}$ & $\begin{array}{l}93.3 \\
87.1\end{array}$ & $\begin{array}{l}13.1 \\
12.6\end{array}$ \\
\hline $\begin{array}{l}2 \\
3\end{array}$ & $\begin{array}{l}21 \mathrm{~min} 46 \mathrm{sec} \\
18 \mathrm{~min} 25 \mathrm{sec}\end{array}$ & $\begin{array}{l}913,546 \\
832,475\end{array}$ & $\begin{array}{l}95.3 \\
86.8\end{array}$ & $\begin{array}{l}16.5 \\
15.1\end{array}$ \\
\hline $\begin{array}{l}1 \\
6\end{array}$ & $\begin{array}{l}65 \mathrm{~min} \\
60 \mathrm{~min}\end{array}$ & $\begin{array}{l}873,719 \\
916,742\end{array}$ & $\begin{array}{l}91.1 \\
95.6\end{array}$ & $\begin{array}{l}47.1 \\
35.8\end{array}$ \\
\hline $\begin{array}{l}7 \\
8 \dagger\end{array}$ & $\begin{array}{l}3 \mathrm{hrs} 29 \mathrm{~min} \\
3 \mathrm{hrs} 18 \mathrm{~min}\end{array}$ & $\begin{array}{l}863,068 \\
834,400\end{array}$ & $\begin{array}{l}90.0 \\
87\end{array}$ & $\begin{array}{l}79.7 \\
81\end{array}$ \\
\hline $\begin{array}{r}9 \\
10\end{array}$ & $\begin{array}{l}23 \mathrm{hrs} 58 \mathrm{~min} \\
23 \mathrm{hrs} 52 \mathrm{~min}\end{array}$ & $\begin{array}{l}690,919 \\
685,102\end{array}$ & $\begin{array}{l}72.0 \\
71.4\end{array}$ & $\begin{array}{l}88.5 \\
86.3\end{array}$ \\
\hline
\end{tabular}

* The times listed were taken at the midpoint of the brief interval during which aortic blood was being withdrawn. + Because of the loss of the whole blood and red cell samples of rat no. 8, the values given for this rat contain a slight degree of uncertainty, since they include estimates of the red cell values based on the results of rat no. 7 . 
TABLE IV

The distribution in tissue of $C^{14}$-cholesterol after intervals varying from 5 minutes to 24 hours*

\begin{tabular}{|c|c|c|c|c|c|c|c|c|c|c|}
\hline $\begin{array}{cc}\text { Rat no. } \\
\text { Time }\end{array}$ & $5 \stackrel{4}{\mathrm{~min}}$ & $\stackrel{5}{5} \mathrm{~min}$ & $20 \stackrel{2}{\min }$ & $20 \stackrel{3}{\mathrm{~min}}$ & $60 \stackrel{1}{\mathrm{~min}}$ & $60^{6} \mathrm{~min}$ & $3_{2}^{\frac{7}{2}}$ hours & $\begin{array}{c}8 \\
3 ! \text { hours }\end{array}$ & 24 hours & $\begin{array}{l}10 \\
24 \text { hours }\end{array}$ \\
\hline $\begin{array}{l}\text { Plasma } \\
\text { Red cells } \\
\text { Liver } \\
\text { Fat } \\
\text { Adrenals } \\
\text { Kidneys } \\
\text { Spleen } \\
\text { Skel. muscle } \\
\text { Heart vent. } \\
\text { Lungs } \\
\text { Rest of carcass }\end{array}$ & $\begin{array}{l}54.0 \\
1.07 \\
34.22 \\
2.71 \\
0.084 \\
0.56 \\
1.63 \\
2.80 \\
2.07 \\
0.85 \\
0\end{array}$ & $\begin{array}{l}51.8 \\
0.94 \\
38.33 \\
2.45 \\
0.104 \\
0.81 \\
1.85 \\
2.24 \\
1.03 \\
0.47 \\
0\end{array}$ & $\begin{array}{c}3.40 \\
0.30 \\
89.54 \\
0.47 \\
0.079 \\
0.034 \\
1.91 \\
0.55 \\
0.11 \\
0.22 \\
3.4\end{array}$ & $\begin{array}{c}2.74 \\
0.70 \\
86.36 \\
3.26 \\
0.11 \\
0.041 \\
2.57 \\
0.62 \\
0.25 \\
0.13 \\
3.2\end{array}$ & $\begin{array}{l}0.56 \\
0.93 \\
89.02 \\
0.46 \\
0.057 \\
0.063 \\
1.87 \\
1.50 \\
0.048 \\
0.18 \\
5.3\end{array}$ & $\begin{array}{l}0.43 \\
0.69 \\
93.33 \\
0.72 \\
0.045 \\
0.034 \\
1.82 \\
0.79 \\
0.030 \\
0.16 \\
2.0\end{array}$ & $\begin{array}{c}5.17 \\
8.17 \\
67.33 \\
1.87 \\
0.246 \\
0.41 \\
1.94 \\
5.08 \\
0.13 \\
1.03 \\
8.6\end{array}$ & $\begin{array}{c}6.63 \\
\dagger \\
66.36 \\
2.08 \\
0.221 \\
0.40 \\
2.49 \\
4.34 \\
0.22 \\
1.50 \\
\dagger\end{array}$ & $\begin{array}{r}4.23 \\
12.77 \\
20.87 \\
4.83 \\
1.53 \\
0.90 \\
3.08 \\
15.49 \\
0.41 \\
3.12 \\
32.8\end{array}$ & $\begin{array}{r}6.34 \\
12.08 \\
18.65 \\
6.98 \\
1.28 \\
0.99 \\
2.70 \\
17.48 \\
0.42 \\
3.13 \\
30.0\end{array}$ \\
\hline
\end{tabular}

* Values listed are the percent of the total recovered $\mathrm{C}^{14}$ present in each tissue.

$\uparrow$ Not accurately determinable because of loss of red cell and whole blood samples in this rat.

contained $18.0 \mathrm{mg}$ total lipid, $0.72 \mathrm{mg}$ total cholesterol, and $1.20 \mathrm{mg}$ phospholipid.

In the subsequent study, each rat received an intravenous injection of $2 \mathrm{ml}$ of the chylomicron suspension, containing $959,060 \mathrm{cpm}$ of $\mathrm{C}^{14}$-cholesterol, 13.1 per cent present as free cholesterol. Two animals were studied after each of 5 intervals, namely, 5, 20, and 60 minutes, and $3 \frac{1}{2}$ and 24 hours. The exact time interval for each animal is listed in Table III. At the end of the study, the observed recovery of $\mathrm{C}^{14}$ in each tissue and carcass extract was summed for each rat and the total recovery of $\mathrm{C}^{14}$ determined. These values are listed in Table III, both as the actual radioactivity in cpm recovered and as the percentage of the $\mathrm{C}^{14}$ dose administered. The measured recovery of $\mathrm{C}^{14}$ as free and as esterified cholesterol was then separately summed for each rat. The last column of Table III shows that after 5 minutes the percentage of $\mathrm{C}^{14}$ present in the animal as free cholesterol was unchanged from the corresponding value in the injected chylomicra. By 20 minutes slightly more of the $\mathrm{C}^{14}$-cholesterol was present as free cholesterol, whereas by 60 minutes the percentage of free cholesterol- $\mathrm{C}^{14}$ had risen to about 40 per cent, and by $31 / 2$ hours to 80 per cent.

The distribution in tissue of $\mathrm{C}^{14}$-cholesterol in each rat is listed in Table IV. After 5 minutes, more than half the $\mathrm{C}^{14}$ was still present in the blood, whereas by 20 minutes less than 5 per cent of the radioactivity was found in the blood. Most of the $\mathrm{C}^{14}$-cholesterol was taken up by the liver, which contained 85 to 90 per cent of the radioactivity at 20 minutes, and 89 to 93 per cent at 60 minutes. The amount of $\mathrm{C}^{14}$ in the liver then declined slowly, so that by $3 \frac{1}{2}$ hours 66 per cent of the $\mathrm{C}^{14}$-cholesterol was found there, and by 24 hours only 20 per cent. No other tissue played a significant role in the initial uptake of $\mathrm{C}^{14}$-cholesterol from the blood. By 24 hours, however, considerable redistribution of labeled cholesterol had taken place, with significant amounts of $\mathrm{C}^{14}$ present in a variety of tissues.

The percentage of $\mathrm{C}^{14}$ present as free cholesterol in each tissue of each rat is given in Table V. Most of the tissues displayed the same general pattern: a low percentage-compared with the injected material-of free $\mathrm{C}^{14}$-cholesterol at 5 minutes, increasing steadily to 80 per cent or more at $31 \% 2$ hours, and to 90 per cent or more at 24 hours. Striking departures from this pattern were observed with red cells, plasma, and the adrenal glands. With the red cells, almost half the $\mathrm{C}^{14}$ found after 5 minutes was present as free cholesterol, and by 60 minutes the amount free was in excess of 99 per cent. It is probable that most of the small amount of $\mathrm{C}^{14}$ associated with the red cells during the first hour derived from direct exchange of free cholesterol between the red cells and the circulating chylomicra. With plasma. the free cholesterol never exceeded 33 per cent. and by 24 hours was less than 20 per cent of the total $\mathrm{C}^{14}$-cholesterol present. Still another pattern was observed in the adrenal glands, where the free cholesterol rose from 11 to 15 per cent at 20 minutes to 50 to 60 per cent at 60 minutes, remained at approximately the same level -45 to 55 per cent at 3\% hours-for at least $2 \frac{1}{2}$ hours, and 
TABLE $\mathrm{V}$

Percentage of $C^{14}$-cholesterol present as free cholesterol in each tissue of each rat *

\begin{tabular}{|c|c|c|c|c|c|c|c|c|c|c|}
\hline Tissue $\begin{array}{c}\text { Rat no. } \\
\text { Time }\end{array}$ & $\stackrel{4}{\min }$ & $5 \stackrel{5}{\min }$ & $20 \stackrel{2}{\min }$ & $20 \stackrel{3}{\mathrm{~min}}$ & $60 \stackrel{1}{\min }$ & $60 \stackrel{6}{\mathrm{~min}}$ & $\begin{array}{c}7 \\
3 \frac{1}{2} \\
\text { hours }\end{array}$ & $\begin{array}{c}8 \\
3 \frac{1}{2} \\
\text { hours }\end{array}$ & 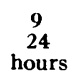 & $\begin{array}{c}10 \\
24 \\
\text { hours }\end{array}$ \\
\hline Whole blood & 14.5 & 13.8 & 24.0 & 21.4 & 71.3 & 70.8 & 71.3 & lost & 79.2 & 72.1 \\
\hline Plasma & 13.8 & 13.2 & 18.0 & 14.4 & 24.6 & 25.6 & 26.4 & 33.3 & 16.8 & 19.6 \\
\hline Red cells & 49.9 & 45.7 & 90.4 & 48.8 & 99.1 & 99.1 & 99.7 & lost & 99.8 & 99.6 \\
\hline Liver & 11.8 & 11.5 & 16.1 & 14.6 & 46.0 & 34.7 & 79.5 & 81.7 & 89.6 & 88.2 \\
\hline Fat & 15.6 & 13.4 & $\sim 26$ & 17.1 & 75 & 74 & 96 & 92 & 93 & 90 \\
\hline Adrenals & 12.7 & 11.5 & 15.3 & 11.1 & 61 & 49 & 45.3 & 56.0 & 9.8 & 11.0 \\
\hline Kidneys & 13.9 & 14.1 & $\sim 26$ & $\sim 27$ & 79 & 58 & 84.2 & 78.0 & 92.6 & 93.1 \\
\hline Spleen & 14.6 & 15.2 & 33 & 26.6 & 85.5 & 76.1 & 93.2 & 93.7 & 96.4 & 95.3 \\
\hline Skel. muscle & $\sim 30$ & $\sim 20$ & $\sim 28$ & $\sim 20$ & 67 & 63 & 97 & 88 & 93.4 & 93.9 \\
\hline Heart vent. & 15.2 & 16.5 & 17.4 & 18.5 & 59 & 67 & 84.9 & 65.2 & 96.0 & 94.2 \\
\hline Lungs & 12.6 & 14.8 & 39.1 & 31.3 & 71.5 & 64.3 & 91.2 & 85.6 & 97.6 & 94.9 \\
\hline
\end{tabular}
$\sim \operatorname{sign}$.

* Where some uncertainty exists because of the small number of cpm analyzed, the value listed is preceded by the

finally declined to a value of 10 per cent $\cdot$ at 24 hours.

Some of the data of Tables IV and V are also presented graphically in Figure 1. In each part of the figure, the percentages of the total recovered $\mathrm{C}^{14}$ found in the tissue are plotted as solid bars, referable to the scale on the left ; the percentages of $\mathrm{C}^{14}$ in the tissue present as free cholesterol are plotted as hatched bars, referable to the scale on the right. Each bar represents the average of the values for the appropriate pair of animals. A and $\mathrm{B}$ present the data for the two quantitatively most important tissues, namely, liver and whole blood. The pattern in whole blood is, of course, the result of the combination of two very different patterns for plasma and for red blood cells. $\mathrm{C}$ is representative of the pattern found in most tissues, and presents the data for fat. D presents the unusual pattern observed in the adrenal gland.

Table VI summarizes the fatty acid composition of the cholesterol ester fraction of rat liver, serum, and adrenal glands. The amount of cholesterol
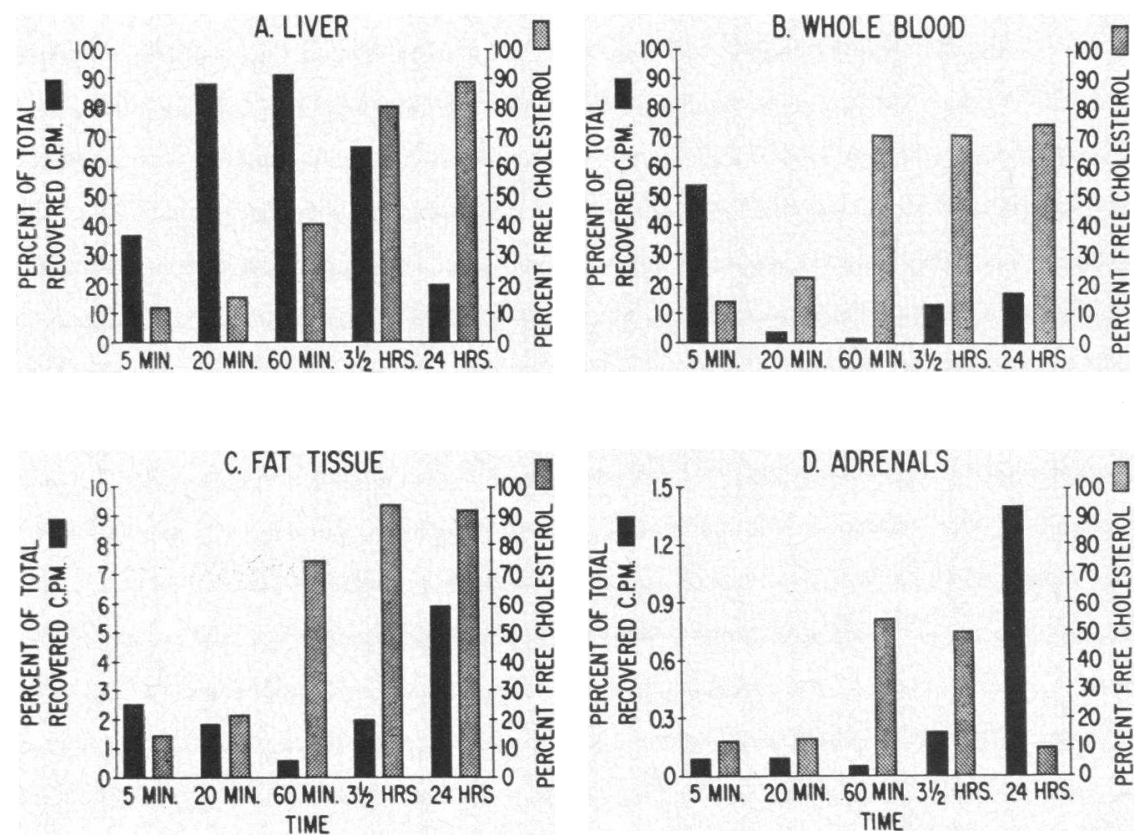

Fig. 1. Role of the liver (A), whole blood (B), adipose tissue (C), ANd adrenal GLANDS (D) IN THE METABOLISM OF CHYLOMICRON CHOLESTEROL ESTERS. 
TABLE VI

Fatty acid composition of the cholesterol ester fraction of rat liver, serum, and adrenal glands

\begin{tabular}{|c|c|c|c|c|}
\hline \multirow{2}{*}{$\begin{array}{l}\text { Fatty } \\
\text { acid }{ }^{*}\end{array}$} & \multirow{2}{*}{$\begin{array}{c}\text { Relative } \\
\text { retention } \\
\text { timet }\end{array}$} & \multicolumn{3}{|c|}{$\%$ of Total fatty acids } \\
\hline & & Liver & Serum & Adrenals $\neq$ \\
\hline Unid. & 0.25 & $\S$ & trace & 0.4 \\
\hline $14: 0$ & 0.29 & 0.9 & 0.6 & 2.5 \\
\hline Unid. & 0.32 & 0.4 & $\S$ & $\S$ \\
\hline $15: 0$ & 0.40 & 0.5 & 0.9 & 1.1 \\
\hline Unid. & 0.425 & 0.4 & $\S$ & $\S$ \\
\hline $16: 0$ & 0.54 & 15.4 & 12.1 & 12.9 \\
\hline $16: 1$ & 0.612 & 6.0 & 4.2 & 3.0 \\
\hline Unid. & 0.824 & 1.7 & 0.7 & 0.6 \\
\hline $18: 0$ & 1.00 & 6.1 & 2.0 & 4.6 \\
\hline $18: 1$ & 1.11 & 45.3 & 20.0 & 17.7 \\
\hline $18: 2$ & 1.33 & 18.8 & 34.7 & 6.7 \\
\hline Unid. & 1.52 & 8 & 8 & 0.7 \\
\hline $18: 3$ & 1.69 & 0.9 & 0.7 & $\S$ \\
\hline 20:0 & 1.83 & 8 & $\S$ & 1.0 \\
\hline Unid. & 2.04 & $\S$ & $\S$ & 2.8 \\
\hline Unid. & 2.73 & $\S$ & $\S$ & 3.4 \\
\hline $20: 4$ & 3.00 & 3.4 & 24.2 & 17.8 \\
\hline $22: 4 \|$ & 5.45 & $\S$ & $\S$ & 17.0 \\
\hline Unid. & 6.84 & $\S$ & $\S$ & 4 \\
\hline Unid. & 7.60 & $\S$ & $\S$ & 4 \\
\hline
\end{tabular}

* The abbreviation system used is that of Dole and co-workers $(21)$; unid. = unidentified.

† Relative to methyl stearate (taken as 1.00 ).

$\ddagger$ Because of the large number of unidentified peaks in the adrenal sample, an experiment was performed to prove that all the peaks represented fatty acid methyl esters. The sample was saponified, the nonsaponifiable compounds extracted with petroleum ether, and the fatty acids then extracted with petroleum ether after acidification. These acids were again methylated and chromatographed. All the peaks were still present, and the pattern obtained was almost identical with the original one. The values given are average values for the two analyses.

$\$$ Not detectable at a level of 0.4 per cent of total.

II Tentative identification (see text).

present in each tissue and the percentage present as free cholesterol are shown in Table VII. The composition of fatty acid esterified with cholesterol of each tissue was distinctly different from that of the others. Oleic acid (18:1) was the main component in liver, 45 per cent of the total, with linoleic acid (18:2) representing 19 per cent of the total, and arachidonic acid $(20: 4)$ only 3.4 per cent. In contrast, the essential fatty acids linoleic and arachidonic, each present as a major peak (linoleic $>$ arachidonic), together comprised almost 60 per cent of the total serum cholesterol

TABLE VII

Cholesterol content of rat liver, serum, and adrenal glands

\begin{tabular}{lcc}
\hline Tissue & $\begin{array}{c}\text { Total choles- } \\
\text { terol } \\
\text { mg per } \mathrm{g} \\
\text { or per } \mathrm{ml}^{*}\end{array}$ & $\begin{array}{c}\text { Free choles- } \\
\text { terol } \\
\% \text { of total }\end{array}$ \\
\hline Serum & 0.71 & 30 \\
Liver & 3.17 & 82 \\
Adrenals & 39.6 & 9.0
\end{tabular}

* Per g tissue wet weight or per $\mathrm{ml}$ serum. ester fatty acids. In the adrenal glands, oleic and arachidonic acids were the two major components, at about 18 per cent each, with linoleic acid comprising only 7 per cent; a large peak, 17 per cent of the total, had a retention time considerably longer than that of arachidonate. This latter compound has been identified as a polyunsaturated straight-chain fatty acid with 22 carbons by rechromatography of the fatty acids after saturation of all double bonds by reduction with hydrogen gas, with palladium on charcoal as catalyst. Comparison of its retention time with those of known standards and with published values (22) suggests that it contains 4 double bonds, although this conclusion can only be considered tentative. Similar considerations suggest that the two final fatty acids listed in Table VI, each accounting for 4 per cent of the total adrenal fatty acids esterified with cholesterol, are also 22-carbon straight-chain fatty acids, with 5 and 6 double bonds, respectively.

Similar analyses of the fatty acid composition of rat liver and serum cholesterol esters have previ- 
ously been reported by Klein and Janssen (23) and by Swell, Law, Field, and Treadwell (24). The present results agree with those of Swell and co-workers (24), who observed a very high percentage of essential fatty acids in serum cholesterol esters and only a relatively small fraction of polyunsaturated fatty acids in liver cholesterol esters. Arachidonic acid was reported to be the major serum fatty acid esterified with cholesterol. In contrast, Klein and Janssen (23) found much less of polyunsaturated fatty acids in serum cholesterol esters, with oleic acid as the main constituent. These latter workers employed silicic acid column chromatography of the sterol ester fraction for quantitative analysis of its composition, whereas Swell and co-workers used gas-liquid chromatography of the fatty acid methyl esters. Some of the differences might be due to the analytic methods employed, although it is probable that the differences mainly reflect the use of different strains of rats, with different dietary histories. In addition, the fatty acid composition of the adrenal cholesterol ester fraction observed here is very similar to that reported by Dailey, Swell, Field, and Treadwell (25) in an extensive study of the adrenal cholesterol ester fatty acid composition of several species.

\section{DISCUSSION}

The in vitro equilibrations with blood served effectively to remove most of the free $\mathrm{C}^{14}$-cholesterol from the chylomicra, resulting in a chylomicron preparation containing 87 per cent of its radioactivity as esterified cholesterol. Recent studies in this laboratory have indicated that the process of cholesterol esterification during fatty acid absorption in rats shows a distinct preference for oleic acid (26). Since the $\mathrm{C}^{14}$-cholesterol used here was fed dissolved in olive oil, which contains oleic acid as its main fatty acid component, it can be inferred that most of the radioactivity in the final preparation resided in cholesteryl oleate. The tissue data can, therefore, be considered most closely to represent the metabolism of this particular sterol ester in chyle.

The recovery of 87 to 96 per cent of the injected radioactivities from the animals during the first $31 / 2$ hours shows that the methods used were satisfactory. By 24 hours the recovery of $\mathrm{C}^{14}$ decreased to 72 per cent; this decrease was probably due to the fecal excretion of $\mathrm{C}^{14}$-labeled sterol and bile acids during the experimental period. In addition, about one-third of the radioactivity recovered from the rats at 24 hours was found in tissues other than those examined, i.e., in the rest of the carcass (see Table IV). Most of this was undoubtedly located in the intestinal contents and tissue, which had not been taken for separate study.

The data presented in Tables IV, V, and Figure 1 provide an over-all picture of the metabolic fate of esterified cholesterol in chylomicra. Upon entry into the vascular compartment, more than 90 per cent of the esterified cholesterol in the chylomicra was rapidly removed by the liver. Removal was 35 to 40 per cent complete in 5 minutes, and 90 to 95 per cent complete in 20 minutes. The uptake of esterified cholesterol by the liver was apparently achieved without hydrolysis, since at short time intervals the percentage of labeled cholesterol present as free cholesterol was unchanged from that in the injected chylomicra. The possibility that uptake by the liver involved hydrolysis and re-esterification cannot be ruled out by the present experiments, but the rapidity of liver uptake and the identity of the percentage of free $\mathrm{C}^{14}$ cholesterol in the liver and injected chylomicra render this unlikely.

In the liver, the newly absorbed esterified cholesterol underwent a slow net hydrolysis. Thus the free $\mathrm{C}^{14}$-cholesterol in the liver rose from 13 to 40 per cent in one hour and to 80 per cent in $3 \frac{1}{2}$ hours. Here, too, the possibiltiy exists that during this period a significant amount of reesterification of the cholesterol took place, so that the actual amount of hydrolysis may have been much greater than the observed net hydrolysis. In vitro studies of the enzymatic hydrolysis of cholesterol esters by rat liver have, however, suggested that the maximal hydrolytic capacity for long-chain fatty acid esters of cholesterol is of the order of magnitude of the net hydrolysis observed here (15). It is, therefore, possible that there was little re-esterification in the liver, and only the slow hydrolysis shown in Figure 1.

During and after hydrolysis, there was a progressive slow loss of $\mathrm{C}^{14}$-cholesterol from the liver as equilibration occurred between the cholesterol pools of liver, blood, and peripheral tissues. These equilibrations extended throughout the experi- 
mental period and were reflected in a slow rise in the $\mathrm{C}^{14}$ content of the various tissues studied. In contrast to the situation during the first hour, after 24 hours there was a considerable amount of radioactivity present in the peripheral tissues, e.g., 15 to 18 per cent in skeletal muscle and 5 to 7 per cent in depot fat. More than 90 per cent of this radioactivity was present in the peripheral tissues as free cholesterol, a finding consistent with the hypothesis that transfer of label to the tissues mainly occurred by equilibration of the free cholesterol pools of liver, blood, and other tissues.

After 24 hours, only plasma and the adrenal glands contained much more esterified than free $\mathrm{C}^{14}$-cholesterol. Both plasma and adrenals normally contain mostly esterified cholesterol, with a normal percentage of free cholesterol similar to the $\mathrm{C}^{14}$ distribution observed here at 24 hours (see Table VII). This suggests that the preponderance of esterified $\mathrm{C}^{14}$-cholesterol in plasma and adrenals at 24 hours resulted from an almost complete equilibration of the free and esterified cholesterol pools in each location. It is, of course, well-known that the equilibration of plasma free and esterified cholesterol depends upon the metabolic activity of the liver. One would like to know, however, whether any of the unhydrolyzed esterified $\mathrm{C}^{14}$-cholesterol from the chylomicra was incorporated directly into plasma lipoproteins in the liver. The present experiments do not provide an answer to this question. It is also possible that esterified $\mathrm{C}^{14}$-cholesterol was preferentially taken up directly from the plasma by the adrenal glands. The data in $\mathrm{D}$ of Figure 1 show that during the early phases of the rise in $\mathrm{C}^{14}$ content in the adrenal glands, i.e., during the period between 1 and $3 \frac{1}{2}$ hours, more than 50 per cent of the adrenal $\mathrm{C}^{14}$ was present as free cholesterol. This suggests that the label first appeared in the adrenal free cholesterol pool, only later to be converted to esterified $\mathrm{C}^{14}$-cholesterol by esterification in situ. Other suggestive evidence in support of this conclusion comes from the data in Table VI, which show that the fatty acid composition of cholesterol esters from rat adrenal glands is distinctly different from the composition of those of plasma or liver. This conclusion must, however, be considered only tentative because of the limitations of the data.

It should be mentioned again that all the rats used were fasted before and during the experiments. Studies with triglyceride-labeled chylomicra have shown that the rate of clearing of injected chylomicra from the blood is not affected by carbohydrate feeding (8), whereas the distribution in tissue of labeled fatty acids after $10 \mathrm{~min}$ utes is different in carbohydrate-fed and fasted rats (9). Preliminary experiments in this laboratory have suggested that the general pattern of cholesterol metabolism observed here is not altered when carbohydrate-fed rats are employed. In addition, it should be stressed that the cholesterol ester fraction of chyle is a mixture of several different individual cholesterol esters, each of which may be differently metabolized. Although the present studies employed mainly labeled cholesteryl oleate, a considerable degree of inhomogeneity was undoubtedly present.

The finding that more than 90 per cent of the chylomicron cholesterol ester is rapidly taken up by the liver raises the interesting question of whether this is also true for the whole chylomicron. It is known that the rates of clearance of chylomicron triglyceride and phospholipid from plasma are identical (7), and studies in this laboratory have shown that the rate of clearance of chylomicron triglyceride in rats is similar to the $\mathrm{C}^{14}$-cholesterol disappearance rate observed here. These data suggest that chylomicra may be removed from the circulation as intact units by the liver. The importance of the liver in the uptake of chylomicron triglyceride fatty acids from the blood was shown in the tissue distribution studies of Bragdon and Gordon (9). These studies also demonstrated, however, that other tissues, particularly skeletal muscle and fat, contained considerable amounts of the triglyceride fatty acids after 10 minutes; this was especially true in the carbohydrate-fed rat. More recent experiments by Nestel, Havel, and Bezman have indicated that a significant fraction of chylomicron triglyceride fatty acid is directly removed from the circulation by extrahepatic tissues (27). This conclusion is also supported by the studies of chylomicron triglyceride metabolism of Olivecrona and Borgström (personal communication). In addition, experiments using chylomicra labeled in both the glycerol and fatty acid parts of the triglycerides have suggested that triglyecides are taken up intact by the liver, but not by adipose tissue (10). It 
therefore seems reasonable to conclude that a considerable part of the whole chylomicron may be taken up intact by the liver. Significant amounts of triglyceride fatty acids are also removed, perhaps with accompanying hydrolysis, during circulation through adipose and other extrahepatic tissues. In the liver, the chylomicron triglycerides are rapidly hydrolyzed, re-esterified into phospholipids and new triglycerides, and partly recirculated in the blood as free and as esterified fatty acids. In contrast, the metabolism of the cholesterol esters proceeds at a relatively sluggish rate, with an over-all pattern very different from that of the accompanying triglyceride and extending over many hours as described above.

\section{SUMMARY}

Chylomicrons labeled with $\mathrm{C}^{14}$-cholesterol were equilibrated in vitro with blood, in order to remove selectively the more readily exchangeable free $\mathrm{C}^{14}$-cholesterol. The resulting chylomicrons, containing 87 per cent of the $\mathrm{C}^{14}$ as esterified cholesterol, were then injected intravenously into fasting rats, and the distribution in tissue and free: ester ratio, of $\mathrm{C}^{14}$-cholesterol were determined at time intervals varying from 5 minutes to 24 hours. Removal of $\mathrm{C}^{\mathbf{1 4}}$-cholesterol from the circulation was very rapid; after 5 minutes only 50 to 55 per cent of the injected $\mathrm{C}^{14}$ was present in the blood, and after 20 minutes only about 5 per cent. Most of the $\mathrm{C}^{14}$-cholesterol was taken up by the liver, which contained 85 to 90 per cent of the radioactivity at 20 minutes, and 89 to 93 per cent at 60 minutes. No other tissue played a quantitatively significant role in the initial uptake of $\mathrm{C}^{14}$ cholesterol from the blood. The uptake of esterified cholesterol by the liver was apparently achieved without hydrolysis, since at short time intervals the percentage of labeled cholesterol present as free cholesterol was unchanged from that in the injected chylomicrons. In the liver, a slow net hydrolysis of the $\mathrm{C}^{14}$-cholesterol ester then occurred, with a rise in the liver free $\mathrm{C}^{\mathbf{1 4}}$-cholesterol from 13 to 40 per cent in 1 hour and to 80 per cent in $3 \frac{1}{2}$ hours. Concomitant with hydrolysis was a progressive slow loss of $\mathrm{C}^{14}$-cholesterol from the liver as equilibration occurred between the cholesterol pools of liver, blood, and peripheral tissues. After 24 hours only 20 per cent of the $\mathrm{C}^{14}$ was found in the liver, with considerable amounts present in the peripheral tissues. Most90 per cent or more - of this radioactivity was present in the peripheral tissues as free cholesterol. Of the tissues examined, only plasma and the adrenal glands contained more esterified than free $\mathrm{C}^{14}$-cholesterol after 24 hours. The possible interpretations of this finding are discussed.

Gas-liquid chromatographic analyses revealed distinctly different fatty acid compositions in the cholesterol ester fractions of rat liver, serum, and adrenal glands. Cholesteryl oleate was the predominant sterol ester in liver, whereas cholesteryl linoleate and arachidonate were the major esters in serum. The adrenal cholesterol ester fraction contained three major fatty acid components: oleic acid, arachidonic acid, and a fatty acid tentatively identified as a 22 -carbon acid with 4 double bonds.

\section{ACKNOWLEDGMENT}

The expert technical assistance of Miss Margaret Dedeian is gratefully acknowledged.

\section{REFERENCES}

1. Chaikoff, I. L., Bloom, B., Siperstein, M. D., Kiyasu, J. Y., Reinhardt, W. O., Dauben, W. G., and Eastham, J. F. $\mathrm{C}^{14}$-Cholesterol. I. Lymphatic transport of absorbed cholesterol-4-C ${ }^{14}$. J. Biol. Chem. 1952, 194, 407.

2. Biggs, M. W., Friedman, M., and Byers, S. O. Intestinal lymphatic transport of absorbed cholesterol. Proc. Soc. exp. Biol. (N. Y.) 1951, 78, 641.

3. Swell, L., Trout, E. C., Jr., Hopper, J. R., Field, H., Jr., and Treadwell, C. R. Mechanism of cholesterol absorption. I. Endogenous dilution and esterification of fed cholesterol-4-C ${ }^{14}$ J. Biol. Chem. 1958, 232, 1.

4. Daskalakis, E. G., and Chaikoff, I. L. The significance of esterification in the absorption of cholesterol from the intestine. Arch. Biochem. 1955, 58, 373.

5. Borgström, B., Lindhe, B. A., and Wlodawer, P. Absorption and distribution of cholesterol-4-C ${ }^{14}$ in the rat. Proc. Soc. exp. Biol. (N. Y.) 1958, 99, 365.

6. Biggs, M. W. Studies on exogenous cholesterol metabolism in human atherosclerosis with the aid of isotopes. Advanc. biol. med. Phys. 1957, 5, 357.

7. Havel, R. J., and Fredrickson, D. S. The metabolism of chylomicra. I. The removal of palmitic acid-1-C ${ }^{14}$ labeled chylomicra from dog plasma. J. clin. Invest. 1956, 35, 1025.

8. Fredrickson, D. S., McCollester, D. L., and Ono, K. The role of unesterified fatty acid transport in 
chylomicron metabolism. J. clin. Invest. 1958, 37, 1333.

9. Bragdon, J. H., and Gordon, R. S., Jr. Tissue distribution of $\mathrm{C}^{\mathbf{1 4}}$ after the intravenous injection of labeled chylomicrons and unesterified fatty acids in the rat. J. clin. Invest. 1958, 37, 574.

10. Borgström, B., and Jordan, P. Metabolism of chylomicron glyceride as studied by $\mathrm{C}^{14}$-glycerol- $\mathrm{C}^{14}$ palmitic acid labeled chylomicrons. Acta Soc. Med. upsalien. 1959, 64, 185.

11. Bragdon, J. H. $\mathrm{C}^{14} \mathrm{O}_{2}$ excretion after the intravenous administration of labeled chylomicrons in the rat. Arch. Biochem. 1958, 75, 528.

12. Fredrickson, D. S., McCollester, D. L., Havel, R. J., and Ono, $\mathrm{K}$. The early steps in transport and metabolism of exogenous triglyceride and cholesterol in Chemistry of Lipides as Related to Atherosclerosis, I. H. Page, Ed. Springfield, Ill., Chas. C. Thomas, 1958, p. 205 ff.

13. Hagerman, J. S., and Gould, R. G. The in vitro interchange of cholesterol between plasma and red cells. Proc. Soc. exp. Biol. (N. Y.) 1951, 78, 329.

14. Dole, V. P, A relation between non-esterified fatty acids in plasma and the metabolism of glucose. J. clin. Invest. 1956, 35, 150.

15. Deykin, D., and Goodman, DeW. S. Hydrolysis of cholesterol esters by rat liver. Fed. Proc. 1962, 21, 297 , and in preparation.

16. Castor, W. O., Poncelet, J., Simon, A. B., and Armstrong, W. D. Tissue weights of the rat. I. Normal values determined by dissection and chemical methods. Proc. Soc. exp. Biol. (N. Y.) 1956, 91, 122.

17. Horning, M. G., Williams, E. A., and Horning, E. C. Separation of tissue cholesterol esters and triglycerides by silicic acid chromatography. J. Lip. Res. 1960, 1, 482.
18. Stoffel, W., Chu, F., and Ahrens, E. H., Jr. Analysis of long-chain fatty acids by gas-liquid chromatography. Micromethod for preparation of methyl esters. Analyt. Chem. 1959, 31, 307.

19. Sperry, W. M., and Webb, M. A revision of the Schoenheimer-Sperry method for cholesterol determination. J. biol. Chem. 1950, 187, 97.

20. Bragdon, J. H. Colorimetric determination of blood lipids. J. biol. Chem. 1951, 190, 513.

21. Dole, V. P., James, A. T., Webb, J. P. W., Rizack, M. A., and Sturman, M. F. The fatty acid patterns of plasma lipids during alimentary lipemia. J. clin. Invest. 1959, 38, 1544.

22. Farquhar, J. W., Insull, W., Jr., Rosen, P., Stoffel, W., and Ahrens, E. H., Jr. The analysis of fatty acid mixtures by gas-liquid chromatography: construction and operation of an ionization chamber instrument. Nutr. Rev. 1959, 17, no. 8 suppl.

23. Klein, P. D., and Janssen, E. T. The fractionation of cholesterol esters by silicic acid chromatography. J. biol. Chem. 1959, 234, 1417.

24. Swell, L., Law, M. D., Field, H., Jr., and Treadwell, C. R. Cholesterol ester fatty acids in serum and liver of normal and lymph-fistula rats. J. biol. Chem. 1960, 235, 1960.

25. Dailey, R. E., Swell, L., Field, H., Jr., and Treadwell, C. R. Adrenal cholesterol ester fatty acid composition of different species. Proc. Soc. exp. Biol. (N. Y.) $1960,105,4$.

26. Whyte, H. M., Karmen, A., and Goodman, DeW. S. Specificity in fatty acid esterification during fat absorption. J. clin. Invest. 1962, 41, 1412 (abstract), and in preparation.

27. Nestel, P. J., Havel, R. J., and Bezman, A. Extrahepatic removal of chylomicron fatty acids in intact dogs. Fed. Proc. 1962, 21, 290, and personal communication. 